\title{
PEMBERDAYAAN EKONOMI RAKYAT MELALUI PENGUATAN MANAJEMEN ORGANISASI DI INDONESIA
}

\author{
Sofyan Hadi \\ Dosen Tetap dan Kaprodi Komunikasi dan Penyiaran Islam \\ Jurusan Dakwah STAIN Jember \\ Email: hadi_sofy@yahoo.com.
}

\section{ABSTRACT}

Many Non-Governmental Organization (NGO) or NGO implementing the program in rural and urban environments. Their activities are characterized by uplift and empower the poorest people, to encourage wider participation, not bureaucratic and in need of a low cost, and many do experiment in community. The issue is how Non Governmental Organization (NGO) perform its activities and how the government response to the role of social transformation. To address this problem, theoretically use interactive theory, integrative of Gramcian and Community Development of Jim Ife and Susan Kenny. Discussion focused on the responses of government, as is often the activity of NGOs opposed to government policy.

\section{ملخص}

كثير من المنظمة غير الحكومية(NGO) تنفذ البرنامج في البيئات الريفية والحضرية. تتميز أنشطتهمبرفع وتمكين أفقر الناس، لتشجيع أوسعمشاركة، وعدم بيروقراطية وفي حاجة منخفضة التكلفة، وكثير منهم أدوا بتربة في البحتمع. القضية هي كيفية المنظمة غير الحكومية أدت أنشطتها وكيفية استجابة الحلكومة لدور التحول الاجتماعي. لمعالجة هذه المشكلة، باستخدام نظرية تفاعليةنظريا، تكاملية لغرمسيان وتنمية المحتمع لجيم إيفي وسوزان كيني. وتركز النقاش على إستجابات الحكومة، كما هو في كثير من الأحيان على نشاط المنظمات غير الحكومية المعارض للسياسة الحكومية.

Key Words : LSM, Pemberdayaan dan Ekonomi Rakyat, manajemen organisasi 


\section{A. Pendahuluan}

Problema pemberdayaan ekonomi rakyat, selalu menarik untuk dikaji. Sejak Indonesia merdeka masalah ekonomi selalu menjadi prioritas utama pembangunan. Hampir semua Repelita menitikberatkan pada masalah ini. Pertanyaannya adalah mengapa masih cukup tinggi tingkat kemiskinan di Indonesia?. Mengapa ekonomi rakyat seperti terjerat untuk berkembang?

Menurut Martuti, sebelum bangsa Indonesia mengenal sistem ekonomi modern, perekomian rakyat telah berperan penting dalam perekomian nasional. Namun seiring dengan masuknya penjajah Belanda, peran tersebut terus berangsur surut karena terdesak oleh sektor modern dan sektor perdagangan perantara. Meskipun begitu ia dapat terus mempertahankan keberadaannya walaupun secara keseluruhan perkembangannya kian memprihatinkan. Keadaan inilah yang tampaknya telah mendorong upaya peningkatan peran ekonomi rakyat pada masa itu selalu menjadi bagian perjuangan politik kaum pergerakan nasional. ${ }^{1}$

Latar belakang sejarahnya adalah para pendahulu kita membuat satu keputusan, bahwa langkah awal yang harus ditangani setelah merdeka adalah persoalan ekonomi seperti dapat diperhatikan dari pernyataan Panitia Pemikir Siasat Ekonomi yang dibentuk pada tahun 1947. Pada waktu itu, panitia yang diketuai oleh Bung Hatta ini menekankan tentang pentingnya rencana kerjanya yang harus mendasar pada memperbesar tenaga beli rakyat, mengingat rakyat telah menderita kemiskinan dan kesengsaraan hidup. Mereka sadar, melihat kenyataan di zaman kolonial, kekayaan kita sudah terhisap ke negeri Belanda. Pada saat merdeka rakyat Indonesia kurus kering, terpisah daging dan lemaknya. Menjadi miskin dan papa, jadi pasca kemerdekaan, problema yang dihadapi oleh bangsa Indonesia adalah tetap, yaitu ekonomi prioritas utamanya untuk menciptakan kesejahteraan masyarakat. ${ }^{2}$ Meski demikian, banyak penghalang yang terus menghadang. Masih kurang adanya keserasian, kesejahteraan, dan kemitraan di antara pelaku ekonomi. Padahal pemberdayaan ekonomi rakyat meski berangkat dan terarah menuju tiga hal itu.

\footnotetext{
1 Anik Dwi Martuti (1995). Ekonomi rakyat antara gagasan dan realita. Jakarta : Sekretariat Bina Desa, hal. 126

2 Usman Hasan dan Suryanto, Agus. (1997). 1 Juli. Menggugat Pemberdayaan Ekonomi Ummat. PILLAR, hal. 10
} 
Masalah ketertinggalan ekonomi sebenarnya sudah menjadi masalah nasional. Lemahnya ekonomi rakyat secara umum adalah masalah rakyat itu sendiri. Upaya untuk mengangkat rakyat dari ketertinggalan itu, harus dilihat dari akar permasalahannya, baru bisa melangkah kepada aspek perbaikan.

Mengenai pemberdayaan ekonomi rakyat, menjadi suatu hal penting dan sangat mendesak untuk segera selesaikan. Mengingat rakyat miskin di Indonesia merupakan the biggest majority (mayoritas besar) dari bangsa Indonesia. Artinya kalau perekonomian kaum miskin itu baik, maka secara hakiki perekonomian Indonesia juga baik. Tetapi seandainya perekonomian kaum miskin Indonesia terbelakang, maka pada hakikatnya perekonomian Indonesia juga terbelakang. Terdapat tiga masalah yang menjadi sebab kaum miskin bisa terbelakang dari sisi ekonomi, yaitu :

1. Filosofis

Penjajahan terhadap bangsa Indonesia mengakibatkan masyarakat di Indonesia masih banyak berada di bawah garis kemiskinan yang perlu pemberdayaan dari segala multi dimensi termasuk ekonomi.

2. Teknis

Masyarakat Indonesia masih banyak yang belum menguasai sains, teknologi, kapital, manajemen dan pasar.

3. Struktur Politis

Kebijakan ekonomi pemerintah yang kurang mendukung dan mengangkat ekonomi umat, seperti sulitnya dan terbelit-belitnya birokrasi peminjaman bank, proyek-proyek BUMN yang tidak bermitra dengan pengusaha pribumi. ${ }^{3}$

Kebijakan-kebijakan pemerintah yang kurang mendukung dan bahkan menghambat bagi perkembangan ekonomi rakyat, seperti :

a. Undang-Undang Koperasi tahun 1994 yang melarang pendirian koperasi selain Koperasi Unit Desa

b. Peraturan Kredit Perbankan yang sangat birokratis dan menuntut tersedianya agunan yang sering kali tidak terjangkau oleh rakyat kecil

c. Peraturan daerah tentang perijinan usaha kecil yang dirasakan menyulitkan bahkan sering kali menuntut biaya perijinan yang tergolong mahal 
d. Pemberlakuan berbagai potongan oleh Koperasi Unit Desa (KUD), sehingga mengakibatkan penerimaan penghasilan pengusaha kecil

e. Peraturan-peraturan yang mengharuskan nelayan, petani dan perajin menjadi anggota Himpunan Nelayan Seluruh Indonesia (HNSI), Himpunan Kerukunan Tani Indonesia (HKTI), dan Himpunan Perajin Indonesia (HPI), sehingga harus menerima berbagai konsekuensi dari peraturan yang berlaku seringkali mengikat mereka

f. Pemungutan retribusi yang dalam prakteknya seringkali berupa bermacam-macam jenis pungutan sehingga memberatkan para pengusaha kecil. ${ }^{4}$

Berkaitan dengan pengusaha kecil, masih banyak faktor-faktor yang menghambat mereka berkembang, antara lain :

1. Rendahnya pendidikan dan keterampilan

2. Lemahnya manajemen kelompok

3. Ketersediaan modal yang terbatas

4. Adanya ketergantungan dengan pihak luar

5. Berkembangnya budaya konsumerisme

6. Lemahnya posisi tawar dengan pihak luar. ${ }^{5}$

Tidak bisa dipungkiri lembaga atau organisasi sangat penting dalam meningkatkan kesejahteraan ekonomi, sosial dan budaya. Akan sulit apabila individu dari masyarakat ekonomi lemah bergerak atau berusaha sendiri dalam memajukan usahanya, karena berbagai masalah dan kelemahan ada pada mereka seperti modal kecil, sulit mencari kredit modal, jaringan pemasaran produksi ekonomi rakyat yang belum berkembang secara optimal. Lain halnya jika mereka mempunyai organisasi atau lembaga maupun kelompok swadaya, paling tidak permasalahan tersebut bisa dikurangi bahkan bisa diatasi. Masyarakat yang sudah mempunyai kelompok-kelompok swadaya tersebut belum paham tentang masalah organisasi dan cara pengelolaannya secara efektif, efisien dan baik.

4 Yuni Suwarto \& Saiful Bahari. (1995). Pola Pengembangan Ekonomi Rakyat. dalam Suwarto. Yuni dan Aris Santoso (Ed.). Ekonomi rakyat antara gagasan dan realita. Jakarta: Sekretariat Bina Desa, hal. 111.

5 Tim BPP YIS (2002). Peningkatan kesejahteraan masyarakat melalui pendampingan kelompok swadaya. Solo: BPP YIS, hal. 1 
Permasalahan kelembagaan yang ada dalam perekonomian rakyat berkaitan dengan lemahnya kesatuan di antara anggota usaha kecil dalam menanggulangi permasalah usahanya. Kelemahan ini diakibatkan oleh sulitnya memperoleh tenaga penggerak atau pengurus dari lingkungan mereka sendiri yang mampu mengorganisasikan kelompoknya. Permasalahan utama dalam kelembagaan atau organisasi karena belum adanya sumber daya manusia yang mampu mengelola atau mengatur organisasi secara baik dan rapi. Belum rapinya pembagian tugas dalam organisasi menjadikan tumpang tindihnya antara tugas yang satu dengan yang lain sangat kentara. Untuk itu mereka perlu memahami masalah organisasi secara baik dan benar. ${ }^{6}$

Melihat fenomena-fenomena tersebut, anggota-anggota kelompok swadaya tentu akan kesulitan jika mereka berusaha mengatasi permasalahan tersebut sendirian karena lemahnya sumber daya manusia, maupun pendidikannya mereka perlu didampingi oleh institusi-institusi baik pemerintah maupun lembaga swadaya masyarakat yang tentunya kredibel di bidangnya dan memihak pada mereka. Berdasarkan hal itu, Lembaga Swadaya Masyarakat selanjutnya penulis singkat dengan LSM merupakan organisasi masyarakat yang concern terhadap pengembangan masyarakat terutama pemberdayaan ekonomi rakyat. Pemberdayaan ekonomi rakyat merupakan suatu hal yang penting dalam menjawab permasalahan-permasalahan tersebut terutama dalam penguatan manajemen organisasi.

Pemberdayaan ekonomi rakyat melalui penguatan manajemen organisasi merupakan upaya mewujudkan organisasi ekonomi rakyat yang kuat dan mandiri. Begitu halnya dengan USC-Satunama telah melakukan pendampingan-pendampingan terhadap Kelompok Swadaya Masyarakat selanjutnya penulis singkat dengan (KSM) baik.

Pengkajian dan penelitian tentang pemberdayaan ekonomi rakyat melalui penguatan manajemen organisasi pada usaha kecil perlu diadakan, sehingga dapat diperoleh data dan informasi tentang penguatan manajemen organisasi dan hasil yang dicapai.

6 Lily Hidayat (1995). Pengembangan Ekonomi Rakyat Melalui Agribisnis, dalam Suwarto. Yuni dan Aris Santoso (Ed.). Ekonomi Rakyat Antara Gagasan Dan Realita. Jakarta: Sekretariat Bina Desa, hal. 95 
Berbagai fungsi telah dijalankan oleh USC-Satunama selaku LSM. Setidaknya, ia berfungsi sebagai fasilitator, komunikator dan motivator dalam tugas pendampingan. Sebagai komunikator Satunama berusaha menggali potensi sumber daya manusia, alam dan sekaligus mengembangkan kesadaran anggota masyarakat akan kendala maupun permasalahan yang dihadapi. Selaku komunikator, Satu nama harus mau menerima dan memberi informasi dari berbagai sumber untuk dijadikan masukan dalam merumuskan, menangani dan melaksanakan program. Selaku fasilitator, Satunama memberikan pengarahan dalam menggunakan pendekatan, strategi dan teknis dalam pelaksanaan program. Tugas-tugas pendampingan masyarakat itu pada intinya adalah berusaha memperkenalkan ide-ide baru kepada masyarakat pedesaan, yang kemudian diserap dan disebarluaskan oleh penduduk desa itu sendiri.

Dalam berbagai kerja kemasyarakatan itu, Satunama juga telah menjalankan fasilitation roles, educational roles, representational roles dan technical roles. ${ }^{7}$ Tidak mudah, USC-Satunama mengakomodasikan peran-peran idealitas, sehingga perlu pemilahan mana peran yang menjadi prioritas dan mana peran yang secara sukarela.

Saat akan menawarkan dan melaksanakan program itu. Satunama memilih strategi atau cara-cara yang sistematis dan bijak hingga memperoleh kepercayaan masyarakat. Strategi itu meliputi langkah-langkah mengidentifikasi, menamai dan mengartikulasikan masalah dan isu, menganalisis masalah, mengidentifikasi tujuan, mempersiapkan rencana tindakan secara terperinci, melaksanakan rencana tindakan dan mengevaluasi keseluruhan proses. ${ }^{8}$ Lika-liku kegiatan itu akan menjadi pengalaman berharga saat akan mendekati masyarakat pada waktu dan tempat berbeda.

Dalam melaksanakan program-programnya. Satunama juga dihadapkan pada berbagai masalah mulai dari hambatan kultural masyarakat yang akan dipilih atau dikenai sasaran program, masalah keterbatasan kemampuan dalam membuat program yang memenuhi kualifikasi permintaan lembaga donor dan masyarakat sendiri. Seringkali tawaran program Satunama mula-mula direspon dengan nada tak sedap oleh kelompok swadaya masyarakat, bahkan ada yang menganggap akan dijadikan kelinci percobaan.

7 Jim Ife (1997). Community development, Melbourne : Addison Wesley Longman, hal. 201

S Susan Kenny (1994). Developing communities for the future. Melbourne : An International Thomson Publishing Company, hal. 125 
Pemberdayaan dan pembangunan ibarat dua sisi mata uang keping yang tidak dapat dipisahkan, diantara keduanya terdapat dua sisi perbedaan yang signifikan, tetapi berada dalam satu kesatuan yang utuh dan saling membutuhkan. LSM sebagai representasi dari swadaya masyarakat sekarang ini mengalami ambivalensi dan masa-masa yang sulit, disatu sisi berusaha untuk memberdayakan masyarakat umum, kelompok-kelompok swadaya masyarakat (self help group), maupun pemberdayaan yang lainnya baik yang bersifat profit oriented atau juga sebaliknya, di sisi lainnya juga berusaha bagaimana agar "aktivisaktivis"-nya dan "lembaga"-nya" dapat berjalan dan hidup beriringan, bukan hanya sekedar dengan bekerja dengan "sukarela dan ikhlas". Pembangunan terkesan hanya sekedar jargon dari pemerintah, tetapi pada hakekatnya pembangunan adalah menjadi tanggungjawab kita bersama, tentunya dengan porsi dan proporsi yang sesuai dengan kemampuan kita. Masyarakat dan LSM harus berfungsi sebagai sense of balance and controlling dari program pembangunan (pemerintah) yang mana tujuan akhir dari dermaga pelabuhannya adalah masyarakat yang adil dan makmur dengan berkonsep pada people centered, partisipatoris dan sustainable dengan indikator keberhasilannya ditandai dengan; 1) kesejahteraan, 2) masyarakat dapat berfikir kritis, 3) mempunyai akses ke sumber daya, 4) adanya organisasi rakyat yang demokratis, 5) terwujudnya kontrol sosial, termasuk kontrol terhadap negara.

Krisis moneter yang berlanjut menjadi krisis ekonomi sejak Juni 1997 betulbetul menumbangkan stigma kesuksesan pembangunan ekonomi di Indonesia. Indikasi ini terlihat dalam merosotnya Produk Domestik Bruto (PDB). Menurut Kepala BPS Sugito Suwito, bahwa pertumbuhan ekonomi (PDB) diperkirakan minus 10,1 persen. Sedangkan laju inflasi sepanjang tahun ini diperkirakan akan mencapai $80 \%$. Jumlah pengangguran menjadi 80 juta orang dan pendapatan per kapita akan berkisar menjadi US\$300 pada akhir 1998 dari US\$ 1,200 pada awal tahun 1996.

Kerisauan utama yang dirasakan oleh sebagian aktivis LSM, adalah indikasi munculnya "kemiskinan" baru. Di kalangan masyarakat yang selama ini didampingi proses pemberdayaannya, ternyata (kondisinya relatif) sama seperti rakyat lainnya yang tidak didampingi. Mestinya alangkah bijak kalau mereka sudah dapat melepaskan dirinya dari belenggu dominasi ideologi developmentalisme, proses pemberdayaan sosial, ekonomi, dan politik rakyat 
(dampingan LSM itu) jika berjalan sukses, tidak akan ada indikasi munculnya "kemiskinan" baru.

Secara nasional (Indonesia), jikalau program pemberdayaan rakyat oleh LSM selama ini sukses, rakyat dampingan LSM tersebut mestinya tidak terlalu terpuruk seperti masyarakat lainnya ketika terjadi krisis nasional tersebut. Asumsinya mereka sudah mempunyai basis ekonomi yang "tangguh" dan institusi organisasi rakyat yang demokratis. Di lain pihak, malah muncul perila$\mathrm{ku}$ anarkis secara nasional.

\section{B. LSM: Tipologi dan Aktivitasnya}

\section{Lembaga Swadaya Masyarakat (LSM)}

a. Pengertian

Lembaga Swadaya Masyarakat (LSM) dalam literatur asing disebut NGO (Non Govermental Organizations). Menurut Maslyukivska, NGO didefinisikan sebagai berikut:

a) NGO is a non profit making, voluntary, service-oriented/development oriented organization, either for the benefit of members (a grassroots organizations) or other members of the population (an agency). Artinya LSM adalah organisasi yang berorientasi pelayanan atau pembangunan baik untuk keuntungan anggota maupun anggota masyarakat. ${ }^{9}$

b) NGO is an organization of private individuals who believe in certain basic social principles and who structure their activities to bring about development to communities that they are servicing. Artinya organisasi individu-individu swasta yang menyakini prinsip-prinsip sosial dasar tertentu dan yang menyusun kegiatan-kegiatannya dalam menjalankan pembangunan masyarakat yang mereka layani

c) NGO is social development organizations assisting in empowerment of people. Artinya LSM adalah organisasi pengembangan sosial yang membentuk pemberdayaan masyarakat

d) NGO is an organization or group of people working independent of any external control with specific objectives and aims to fulfill task that are

9 Maslyukivska Olena (1999) Role of non-govermental organizations in development coorperation. UNDP/Yale Collaborative Programme: Research Papers, hal. 7 
oriented to bring about describle changes in given community. Artinya LSM adalah organisasi atau kumpulan orang-orang yang bekerja bebas dari control pihak luar dengan tujuan-tujuan khusus dan bertujuan untuk memenuhi tugas-tugas yang diorientasikan untuk membawa perubahan penting pada masyarakat yang dituju.

Sementara itu menurut ADB :

"NGOs are private organizations entirely or largely independent of government, not created for financial or material gain, that addres concerns such as social and humanitarian issues of development, individual and community welfare and well being, disadvantage, poverty and environmental and natural resource protection, management and improvement.

Artinya :

“LSM adalah organisasi swasta yang kebanyakan bebas dari pemerintah, tidak tercipta untuk mendapatkan uang atau material, yang memberikan perhatian pada isu-isu sosial dan kemanusiaan dan pembangunan, kesejahteraan dan kebaikan perorangan dan masyarakat, kesenjangan, kemiskinan dan perlindungan lingkungan dan sumber daya alam, manajemen dan pengembangan". ${ }^{10}$

Definisi NGO versi lain juga dikemukakan oleh Magdolna, dkk. Menurutnya, LSM adalah kumpulan warga akar rumput yang aktifitasnya terorganisir untuk menentang rencana proyek pemerintah atau kumpulan para ahli yang memberi saran kepada pemerintah tentang suatu masalah secara netral atau koalisi dari perwakilan industri yang menyampaikan pemikirannya kepada pemerintah. ${ }^{11}$

LSM termasuk salah satu dari organisasi civil society yang menaruh perhatian pada urusan umum yang ditentukan kelompok sosial dan memobilisasi sumber-sumber melalui nilai-nilai dan visi-visi. Secara luas, organisasi civil society adalah rukun tetangga, gereja-gereja, LSM,

\footnotetext{
${ }^{10}$ Kazi F.Jalal (1999). Study of NGO. regional overview report. Manila: ADB, hal. 5

11 Magdolna Nagy (1 Januari 1994). Manual on public pin Enviromental decision making. "Papers UNDP". Budapest. Diambil pada tanggal 12 Agustus 2000, dari http://www.rec. org/ default.html., hal. 11
} 
koperasi, klub olah raga, kumpulan paduan suara dan perhimpunan lainnya. ${ }^{12}$

Dengan demikian dapat digarisbawahi bahwa LSM paling tidak memiliki ciri-ciri berikut : Pertama, organisasi yang tidak berafiliasi pada lembaga-lembaga politik, umumnya bekerja untuk membantu, mengembangkan dan menyejahterakan masyarakat. Kedua, organisasi yang sangat menaruh perhatian terhadap akar penyebab kemiskinan, ketertekanan dan keterpinggiran masyarakat sehingga terjadi peningkatan kualitas hidupnya. Ketiga, organisasi didirikan oleh dan untuk masyarakat tanpa atau sedikit intervensi dari pemerintah, tidak hanya organisasi dermawan, namun bekerja untuk kegiatan sosioekonomi-kultural. Keempat, organisasi yang luwes dan demokratis dalam pengaturan dan berusaha untuk melayani masyarakat tanpa keuntungan untuk diri sendiri.

b. Tipologi

LSM dapat membuat berbagai bentuk program kegiatan untuk kepentingan masyarakat dengan memaksimalkan sumber daya masyarakat sendiri dan jika terpaksa meminta bantuan pemerintah atau luar negeri. Dalam pengorganisasian program pemberdayaan masyarakat terkandung empat langkah mendasar yaitu perencanaan program, mendorong selfhelp, adanya bantuan teknis dan mengintegrasikan berbagai sektor untuk membantu kemajuan masyarakat. Untuk programprogram teknisnya dapat diklasifikasikan ke dalam tiga kelompok yakni loyality development misalnya pembangunan rumah sehat, social planning misalnya pengumpulan fakta atau penelitian dan social action misalnya advokasi atau pembelaan terhadap hak-hak sipil.

MenurutEldrige, model pendekatan LSMada tiga. Pertama high level partnership : grass roots development yang diwujudkan dengan kerjasama antara LSM dengan program pembangunan resmi seraya mencari peluang untuk mempengaruhi rancangan dan implementasinya agar lebih mengarah kepada partisipatori. Kedua, high level politics : grass

${ }^{12}$ David Brown \& Kalegaonkar, Archana. (1 Juli 1999). Addresing civil society's challenges. IDR Report. Volume 15. Number 2. Diambil pada tanggal 21 Januari 2002. dari http:/ / www.jsj.com/idr/web\%20reports/html/15-2.html. 
roots mobilization yakni LSM menggalakkan gerakan penyadaran sosial, kemampuan mengelola diri sendiri dan kelompok sasaran khusus. Mereka memainkan peranan advocacy dan kurang suka bekerjasama pemerintah. Ketiga, empowerment at the grass roots yakni dengan pemberdayaan masyarakat.

Terdapat empat persepsi diri LSM, Pertama, LSM sebagai bagian integral pemerintah (istilah yang digunakan adalah mitra pemerintah atau sekutu bukan seteru, kawan bukan lawan). Kedua, LSM sebagai mediator antara pemerintah dengan masyarakat (istilahyang digunakan adalah jembatan antara pemerintah dengan masyarakat). Ketiga, LSM yang secara tegas menyatakan memihak rakyat dalam berhadapan dengan negara (istilah yang digunakan pendamping rakyat). Keempat, LSM yang melebur dan menyatu dengan rakyat (istilah yang digunakan adalah menyatu dalam organisasi kelompok basis). ${ }^{13}$

Dilihat dari sifat kegiatannya LSM memiliki empat tipologi. Pertama, relief and welfare agencies seperti kelompok misionaris. Kedua, technical innovation organizations yakni organisasi yang menjalankan proyekproyeknya sendiri untuk memelopori atau mengembangkan pendekatan baru terhadap masalah yang umumnya dalam bidang khusus. Ketiga, public service contractors yakni LSM yang umumnya didanai oleh pemerintah negara-negara maju atau utara (nothern) yang pekerjaannya berhubungan dekat dengan pemerintah selatan (negara berkembang) dan lembaga bantuan resmi. Keempat, popular development agencies yakni LSM negara maju maupun berkembang yang memusatkan perhatian pada selfhelp, pengembangan sosial dan demokrasi rakyat kecil. Kelima, grassroot development organizations yakni organisasi pengembangan yang berbasis kedaerahan di negara berkembang yang anggotanya orang-orang miskin atau tertindas dan berusaha melakukan proses pembangunan secara umum atau murah. Keenam, advocacy groups and networks yakni organisasi tanpa proyek pekerjaan yang secara tujuan keberadaannya untuk pendidikan dan lobby.

13 Ony Prijono (1996). Pemberdayaan; konsep, kebijakan dan implementasi, Jakarta : Centre for Strategic and International Studies (CSIS), hal. 123 
Selain itu, tipe LSM dilihat dari orientasi pekerjaannya setidak-tidaknya dapat diklasifikasikan dalam empat kelompok. Pertama, charitable orientation yakni LSM yang mengarahkan kegiatannya pada pemenuhan kebutuhan orang-orang miskin seperti distribusi makanan, pakaian, obat-obatan, penyedian tempat tinggal, angkutan, sekolah-sekolah dan lain-lain.

Kedua, service orientation yakni LSM dengan kegiatan-kegiatan seperti pelayanan kesehatan, perencanaan keluarga atau pelayanan pendidikan pada program yang disusun oleh LSM dan masyarakat diharapkan berpartisipasi dalam pelaksanaan dan penerimaan pelayanan.

Ketiga, participatory orientation dicirikan dengan proyek selfhelp di mana masyarakat lokal dilibatkan secara khusus dalam pelaksanaan proyek dengan menyumbang uang, alat-alat, tanah, bahan, tenaga, dan lain-lain.

Keempat, empowering orientation yakni bertujuan untuk membantu masyarakat miskin dalam membangun pemahaman secara lebih jelas terhadap faktor-faktor sosial, politik dan ekonomi yang mempengaruhi kehidupannya dan memperkuat kesadarannya akan potensinya sendiri dalam mengendalikan kehidupannya.

Selainitu dalam pandangan John Clark, LSM secara umumjuga dapat dibedakandalam enam aliran yakniagen penyantunan dan kesejahteraan, organisasi pengembangan teknologi, kontraktor pelayanan umum, agen pengembangan/pemberdayaan masyarakat, organisasi pengembangan masyarakat bawah dan kelompok jaringan advokasi. ${ }^{14}$

c. Peranan LSM

Secara terinci peran yang dapat dilakukan LSM seperti USCSATUNAMA meliputi empat hal berikut :

Pertama, facilitative roles yakni peran-peran yang dijalankan pekerja masyarakat dengan memberi stimulan dan dukungan kepada masyarakat. Peran ini meliputi social animation (memberi semangat atau mengaktifkan), mediation and negotiation (menengahi dan menghubungkan), support (mendorong), building consensus (membangun

14 John Clark (1995). Democratizing Development : The Role of Voluntary Organizations. Terjemahan NGO dan Pembangunan Demokrasi. Yogyakarta : Tiara Wacana, hal. 45 
kesepakatan), group facilitation (memfasilitasi atau memperlancar kelompok), utilisation of skills and resources (penggunaan keterampilan dan sumber-sumber) dan organising (mengatur). ${ }^{15}$

Kedua, educational roles yakni peran-peran kependidikan. Dalam pengembangan masyarakat terjadi proses pembelajaran terus-menerus dari masyarakat maupun pekerja kemasyarakatan untuk selalu memperbaharui keterampilan, cara berpikir, cara berinteraksi, cara mengatasi masalah dan sebagainya. Peran ini meliputi conciousnes raising (membangun kesadaran), informing (memberi penjelasan), confronting (mempertentangkan sebagai taktik dinamisasi kelompok), training (pelatihan).

Ketiga, representational roles (peran-peran perwakilan). Peran ini dijalankan oleh pekerja kemasyarakatan dalam interaksinya dengan lembaga luar, atas nama masyarakat dan untuk kepentingan masyarakat. Peran ini meliputi usaha mendapatkan sumber-sumber, melakukan advokasi atau pembelaan masyarakat, membuat mitra atau network, sharing pengalaman dan pengetahuan dan menjadi juru bicara masyarakat.

Keempat, technical roles yakni peran pekerja masyarakat dalam menetapkan ketrampilan teknis untuk mengembangkan masyarakat. Beberapa dimensi pekerjaan kemasyarakatan seperti pengumpulan dan analisis data, pemakaian komputer, penyajian laporan secara lisan dan tertulis, penanganan proyek pembangunan sarana fisik, manajemen dan pengendalian uang sangat membutuhkan keterampilan teknis.

Dalam perspektif lain, peran LSM dapat meliputi enam hal. Pertama, development and operation of infrastructure yakni pembangunan dan pengoperasian infrastruktur seperti pengembangan lahan, pembuatan rumah, penyediaan sarana fisik seperti toilet atau sumur umum dan pengolahan limbah serta bantuan dalam manajemen organisasi.

Kedua, supporting innovation, demonstration and pilot project yakni mendorong usaha inovatif, memberi contoh dalam menangani proyek pengembangan masyarakat secara efektif dibandingkan birokrasi pemerintah.

15 Jim Ife (1997). Community development, Melbourne : Addison Wesley Longman 
Ketiga, facilitating communication yakni menggunakan metode komunikasi ke atas dari masyarakat pada pemerintah dan metode komunikasi ke bawah dari pemerintah ke masyarakat untuk memfasilitasi proyek-proyeknya agar dapat dirasakan masyarakat dan diapresiasi oleh pemerintah.

Keempat, technical assistance and training yakni membantu bantuan teknis dan pelatihan dalam program pengembangan masyarakat.

Kelima, research, monitoring and evaluation yakni melakukan penelitian, pengawasan dan penilaian terhadap hasil-hasil kerja pengembangan masyarakat sehingga hasilnya dapat dibagi dengan masyarakat sendiri.

Keenam, advocacy for and with the poor yakni menjadi juru bicara dan pembela kaum miskin dan berusaha mempengaruhi kebijakan dan program pemerintah untuk kepentingan masyarakat. ${ }^{16}$

\section{Pemberdayaan Ekonomi Rakyat}

1. Pengertian Pemberdayaan Rakyat

Pemberdayaan rakyat didefinisikan sebagai upaya memberi daya atau kekuatan kepada rakyat (empowerment). Pemberdayaan berarti mengembangkan kekuatan atau kemampuan (daya), potensi, sumber daya rakyat agar mampu membela dirinya sendirinya. Hal yang paling inti dalam pemberdayaan adalah peningkatan kesadaran. Rakyat yang sadar adalah rakyat yang memahami hal-hal dan tanggungjawabnya secara politik, ekonomi dan budaya, sehingga sanggup membela dirinya dan menentang ketidakadilan yang terjadi padanya. ${ }^{17}$

Konsep pemberdayaan masyarakat ini berangkat dari ide yang menempatkan manusia sebagai subjek dari dunianya sendiri. Pola dasar gerakan pemberdayaan ini mengamanatkan kepada perlunya power dan menekankan keberpihakan kepada kelompok yang tak berdaya. Pemberdayaan masyarakat merupakan upaya untuk mengentaskan masyarakat miskin, maka masyarakat harus diberdayakan (bukan hanya dipenuhi kebutuhan mereka secara spontan sebab hal ini hanya

16 Maslyukivska Olena (1999), Role ..., hal. 8

17 Esrom Aritonang dkk. (2001). Pendampingan komunitas pedesaan. Jakarta: Sekretariat Bina Desa, hal. 8 
menyelesaikan masalah secara temporer atau jangka pendek) sehingga mereka mampu mengidentifikasi permasalahan sendiri dan juga mencari alternatif pemecahan masalahnya dengan menggali sumbersumber daya di lingkungan mereka sendiri.

Menurut Ife, empowerment means providing people with the resources, opportunities, knowledge and skills to increase their capacity to determine their own future, and to participate in and affect the life of their community, maksudnya pemberdayaan adalah memperlengkapi sumber-sumber, kesempatan, pengetahuan dan keterampilan kepada warga untuk meningkatkan kemampuan mereka dalam menentukan masa depannya sendiri dan berpartisipasi dalam dan mempengaruhi kehidupan dari masyarakatnya. ${ }^{18}$

Berdasarkan penelitian kepustakaan, proses pemberdayaan mengandung dua kecenderungan. ${ }^{19}$ Pertama, proses pemberdayaan menekankan kepada proses memberikan atau mengalihkan sebagian kekuasaan, kekuatan atau kemampuan kepada masyarakat agar individu menjadi lebih berdaya. Proses ini dilengkapi dengan upaya membangun asset material guna mendukung pembangunan kemandirian mereka melalui organisasi. Kecenderungan pemberdayaan jenis disebut kecenderungan primer dari makna pemberdayaan. Kedua, kecenderungan pemberdayaan yang dipengaruhi karya Freire yang memperkenalkan istilah konsientisasi (conscientization). ${ }^{20}$ Konsientisasi merupakan suatu proses pemahaman situasi yang sedang terjadi sehubungan dengan hubungan-hubungan politis, ekonomi dan sosial. Seseorang menganalisis sendiri masalah mereka, mengidentifikasi sebab-sebabnya, menetapkan prioritas dan memperoleh pengetahuan baru. Dalam spektrum ini, pemberdayaan identik dengan kemampuan individu untuk mengontrol lingkungannya. Kesadaran kritis dalam diri seseorang dapat dicapai dengan cara melihat ke dalam diri sendiri serta menggunakan apa yang didengar, dilihat dan dialami untuk memahami apa yang sedang terjadi dalam kehidupannya.

18 Jim Ife (1997). Community ..., hal. 182

19 Ony Prijono (1996). Pemberdayaan..., hal. 7

20 Paulo Freire (1972). Pedagogy of the oppressed. London : Penguin, hal. 19 
Upaya pemberdayaan masyarakat (empowering society) itu mencakup tiga kegiatan penting. ${ }^{21}$ Pertama, berupaya membebaskan dan menyadarkan masyarakat. Kegiatan ini bersifat subyektif dan memihak kepada masyarakat tertindas (dhuafa') dalam rangka memfasilitasi mereka dalam suatu proses pemberdayaan sehingga memungkinkan lahirnya upaya untuk pembebasan diri dari kemiskinan dan keterbelakangan. Kedua, ia menggerakkan partisipasi dan etos swadaya masyarakat.

Konsep pemberdayaan ini muncul sebagai sebuah formula atau tawaran untuk memecahkan problema kemiskinan dalam kehidupan sosial akibat kurang efektifnya program pembangunan. Problema kemiskinan ini telah memperoleh perhatian diantaranya oleh Robert Chambers. Chambers menganalisis penyebab kemiskinan sebagai suatu kompleksitas serta hubungan sebab-akibat yang saling berkaitan dari ketidakberdayaan (powerlesness), kerapuhan (vulnerability), kelemahan fisik (physical weakness), kemiskinan (poverty) dan keterasingan (isolation). Menurut Chambers, ada keterkaitan antara ketidakberdayaan dan dimensi perangkap lain. Ketidakberdayaan membatasi akses terhadap sumber daya negara, memperumit keadilan hukum bagi penyelewengan, menyebabkan hilangnya kekuatan tawar-menawar, membuat rakyat semakin rapuh terhadap permintaan mendadak untuk pembayaran pinjaman atau terhadap permintaan uang suap dalam suatu persengketaan. ${ }^{22}$

Program pemberdayaan masyarakat haruslah memiliki ciri-ciri khusus. Mengacu pendapat Kartasasmita, beberapa ciri khususnya ${ }^{23}$ antara lain :

1) Pemberdayaan haruslah terarah dan berpihak pada yang memerlukan dengan program dirancang untuk mengatasi masalahnya sesuai dengan kebutuhan. Hal ini pada dasarnya terkait dengan pemahaman bahwa program yang dilakukan yaitu tepat dan cepat mengarah pada sasarannya.

21 Yakub (1985). Pondok pesantren dan pembangunan masyarakat desa Bandung: Angkasa, hal. 30-33.

${ }^{22}$ Robert Chambers (1983). Rural development, putting the last first. New York : Longman, hal. 93.

23 Tim BPP YIS (2002). Peningkatan..., hal. 1 
2) Mengikutsertakan masyarakat yang akan dibantu serta sesuai dengan kehendak diri kemampuan masyarakat yang akan dibantu. Hal ini merupakan aktualisasi dari komitmen bahwa etos pemberdayaan harus melibatkan peran sebagai subyek dan bukannya objek (yang terinteraksi satu arah saja).

3) Harus menggunakan proses pendekatan kelompok karena jika dilakukan secara individual maka warga masyarakat yang kurang berdaya akan terasa sulit untuk memecahkan masalah-masalah yang dihadapi. Ini juga untuk menunjukkan bahwa acuan kolektifitas akan mempermudah pemetaan permasalahan yang terjadi.

Pemberdayaan harus diarahkan langsung pada akar persoalannya yaitu meningkatkan kemampuan masyarakat miskin dengan mengembangkan dan mendinamisasikan potensinya (atau merangsang produktivitas), serta memberdayakannya. Secara umum, diyakini bahwa pemberdayaan mempunyai tujuan dua arah, yaitu : pertama, melepaskan belenggu kemiskinan dan keterbelakangan dan yang kedua, memperkuat posisi tawar pada lapisan masyarakat bawah ke dalam struktur kekuasaan yang lebih luas.

Adanyasisipemahamantujuanduaarahtersebut,makapemberdayaan masyarakat diartikan sebagai upaya untuk lebih memberdayakan masyarakat yaitu tidak saja untuk menumbuhkan nilai tambah ekonomi, melainkan juga nilai tambah sosial dan nilai tambah adanya. Konsep ini mencerminkan proses paradigma baru pembangunan yang bersifat people centred (terfokus pada tujuan kesejahteraan penduduk), participatory (keterlibatan secara aktif dari masyarakat), empowering (pemberdayaan secara kontinyu) dan Sustainable (dilaksanakan secara berkelanjutan dan bukannya temporer).

Bentuk, jenis, dan cara pemberdayaan rakyat atau penguatan rakyat tentu sangat beranekaragam. Salah satu cara yang digunakan dalam proses pemberdayaan masyarakat adalah dengan model pendampingan. Model ini mengandaikan bahwa pendampingan dapat berfungsi sebagai fasilitator, mediator, motivator, transformator, 
dinamisator, dan lain-lain, sehingga terjadi transfer of knowledge kepada masyarakat. ${ }^{24}$

Pendampingan masyarakat tidak bisa dilakukan dalam waktu singkat dan dilakukan sesuka hati. Seluruh pekerjaan ini mesti dilakukan secara bersungguh-sungguh. Ada beberapa tahap dalam pendampingan ${ }^{25}$ yaitu :

1) Pengenalan

Tahap ini seorang pendamping mulai mencoba mengenal kelompok dengan cara mengalir, terlibat dalam pertemuan kelompok sosial, mengarahkan semua kepekaan, pengamatan dan penghayatan.

2) Pengakraban diri

Tahap ini tugas pendamping yang terpenting adalah lebih sering ketemu masyarakat, walaupun sebentar-sebentar.

3) Pendalaman subjek

Tahap ini, pendamping sudah mulai bertanya setiap kali terlibat dalam pertemuan kelompok, tentu hal-hal yang umum terlebih dahulu. Dalam mendengar jawaban, jangan berdebat masyarakat dahulu dan jangan seperti sedang melakukan sensus.

4) Analisis

Dalam tahap ini, pendamping telah mengetahui kekuatan dan kelemahan kelompok secara umum. Keterbukaan sudah terjalin. Dalam tahap analisis ini pendamping sudah harus mulai menanyakan hal-hal yang sangat dalam mengenai kelompok, keberadaan kelompok, kelompok luar yang berkepentingan dan sampai juga ke dalam analisis masalah, politik, ekonomi, sosial dan budaya. Dalam hal ini dilakukan juga analisis kebutuhan beserta hambatan dan kendala yang dihadapi oleh kelompok. Dari hasil analisis ini akan muncul sebuah upaya bersama, untuk dapat lepas dari masalah tersebut.

5) Penguatan

Tahap ini merupakan tahap kristalisasi pendampingan, di dalamnya telah terjadi soliditas dari para anggota kelompok serta

24 Heru Nugroho (2000). Menumbuhkan ide-ide kritis. Yogyakarta : Pustaka Pelajar, hal. 45

25 Kurdi Marzuki (2001). Tahapan Pengorganisasiaan Rakyat Sebuah Pengalaman Simpul belajar kita. Jakarta : Yayasan Patria Nusantara, hal. 3-4 
adanya kesadaran akan manfaat kelompok, karena dalam pertemuanpertemuan yang dilakukan sudah mulai membicarakan hal-hal yang strategis, baik intern maupun ekstern. Dalam setiap pertemuan pendampingan sudah mulai menggiring ke arah diskusi kritis obyektif, serta demokratisasi ekonomi, politik dengan tetap melihat intelektual masyarakat setempat

6) Pembuatan jaringan

Tahap ini adalah tahap membuat simpul antara kelompok dampingan satu dengan dampingan lainnya untuk saling kenal dan mengenal aktivitas masing-masing. Sekaligus juga dimaksudkan untuk memunculkan kepercayaan diri, dengan melihat adanya kelompok lain melakukan aktivitas yang sama.

2. Pengertian Ekonomi Rakyat

Menurut Widjaya, bahwa yang dimaksud dengan ilmu ekonomi adalah suatu studi tentang bagaimana individu (produsen maupun konsumen dan masyarakat memilih atau menentukan untuk menggunakan sumber-sumber yang jumlahnya terbatas yang dimilikinya dan yang dapat digunakan secara alternatif untuk memproduksi berbagai barang dan jasa serta mendistribusikannya untuk konsumsi, baik sekarang ataupun di masa depan, di antara para individu atau berbagai golongan di dalam masyarakat. ${ }^{26}$

Melihat definisi di atas, sebenarnya tidak perlu lagi mempermasalahkan apakah namanya menjadi ekonomi kerakyatan ataupun lainnya, karena sudah jelas yang menjadi aktor atau pemain dalam menjalankan roda perekomian dapat seorang individu, golongan atau masyarakat yang notabene mereka itu adalah rakyat-sekelompok/ segenap penduduk dalam suatu negara. Secara normatif tidak ada masalahnya, tetapi dalam kenyataannya menjadi masalah di jaman Orba yang menjalankan roda perekomian hanyalah segelintir orang, kroninya keluarga cendana.

Sebagaimana dikategorikan oleh Sukadji Ranuwihardjo sama uraian di atas, untuk kategori yang lain, ekonomi kerakyatan merupakan ideologi atau mungkin sebagai serangkaian perangkat kebijakan (po-

${ }^{26}$ Faried Wijaya (1987). Pengantar ekonomi. Yogyakarta : Femosa, hal. 1 
ling instruments) bahkan hanya sebagai permainan kata-kata untuk kepentingan kampanye saja. Sukadji, walaupun tidak pasti agak condong pada kategori, sebagai serangkaian perangkat kebijakan yang bersasaran penduduk yang hidup digaris kemiskinan. ${ }^{27}$

Menurut Mubyarto, ekonomi rakyat adalah kegiatan yang dilakukan oleh rakyat yang dengan secara swadaya mengelola sumber daya apa saja yang dapat dikuasainya setempat dan ditujukan untuk memenuhi kebutuhan dasarnya dan keluarganya. ${ }^{28}$ Istilah ekonomi kerakyatan identik dengan masyarakat ekonomi lemah yang biasanya usaha-usaha mereka berskala kecil seperti buruh tani, tani miskin, pengrajin, industri rumah tangga dan lain-lain.

\section{Peran LSM dalam Pemberdayaan Ekonomi Rakyat di Indonesia}

Penelitian yang mengambil fokus pada masalah Peran LSM dalam Pemberdayaan Ekonomi Rakyat di Indonesia agaknya sudah banyak dilakukan peneliti kita. Salah satunya adalah penelitian Disertasi Mansor Fakih (alm) di University of Massachussets at Amherst, USA tahun 1996 dengan judul The Role of Non-Governmental Organization in Social Transformation : A Participatory Inquiry in Indonesia. Disertasi yang dalam edisi berbahasa Indonesia diberi judul : Masyarakat Sipil Untuk Trasnformasi Sosial : Pergolakan Ideologi Di Dunia LSM Indonesia ini memotret kiprah LSM Indonesia pada akhir tahun 80-an dan awal 90-an dalam transformasi sosial di Indonesia.

Dalam temuannya, ideologi aktivis LSM Indonesia secara luas dapat digolongkan menjadi tiga tipologi. Tipe pertama yakni LSM-LSM yang berparadigma konformis. Mereka terdiri atas aktivis LSM yang melakukan pekerjaan mereka didasarkan kepada paradigma karitatif atau sering disebut "bekerja tanpa teori" atau mereka berorientasi pada proyek dan bekerja sebagai organisasi yang menyesuaikan diri dengan sistem dan struktur yang ada. Motivasi utamanya adalah menolong rakyat dan didasarkan pada niat baik untuk membantu mereka yang membutuhkan. Pertanyaan tentang mengapa ada begitu

27 Permono Iswardono (1999). Ekonomi, kerakyatan; sekedar jargon politik, Jurnal Ekonomi dan Bisnis Indonesia, hal. 34-39

28 Mubyarto. (1997). Ekonomi rakyat, program IDT, dan demokrasi ekonomi Indonesia. Yogyakarta : Aditya Media, hal. 3 
banyak rakyat miskin dianggap bukan pertanyaan penting. Di antara mereka Biro Pengembangan Pesantren dan Masyarakat (BPPM) di pondok-pondok pesantren. ${ }^{29}$

Tipe Kedua yakni LSM-LSM yang berparadigma reformisme. Mereka yang memiliki pemikiran yang didasarkan pada ideologi modernisasi dan developmentalisme. Mayoritas (80\%) aktivis LSM percaya atau mengikuti paradigma reformisme. Tesis utamanya adalah bahwa keterbelakangan mayoritas rakyat disebabkan adanya sesuatu yang salah dengan mentalitas dan nilai-nilai rakyat. mentalitas dan nilai-nilai terbelakang dianggap penyebab utama kelemahan partisipasi rakyat dalam pembangunan. Karena itu ia menjadikan peningkatan partisipasi rakyat dalam pembangunan sebagai tema utamanya. Di antara LSM bertipe ini adalah LP3ES, Bina Swadaya, Dian Desa dan YIS serta USC-Satunama Yogyakarta.

Tipe Ketiga yakni LSM-LSM yang berparadigma transformatif. Mereka bersifat alternatif dengan mempertanyakan paradigma mainstream yang ada dengan mendorong ke arah terciptanya superstruktur dan struktur yang memungkinkan rakyat untuk mengontrol perubahan sosial dan menciptakan sejarah sendiri. Baginya, salah satu penyebab masalah rakyat adalah diskursus pembangunan dan struktur yang timpang dalam sistem yang ada. Di antara LSM bertipe ini adalah P3M (Pusat Pengembangan Pesantren dan Masyarakat).

Mansour Fakih dalam penelitian ini juga melihat bahwa menggunakan gerakan LSM sebagai sarana transformasi sosial merupakan hal yang problematis dan menantang terutama dari sisi partisipasi dan representasi. Banyak aktivis LSM yang merasakan proyek mereka sebagai proyek per se dan bukan sebagai bagian dari gerakan untuk perubahan.

Dalam menetap ke depan, LSM Indonesia perlu menegaskan komitmen terhadap suatu agenda perubahan. Agenda ini terdiri atas dua bagian utama yaitu perjuangan ideologis dan politis. Agenda ideologi pada dasarnya mengembangkan mekanisme internal dan eksternal gerakan LSM untuk menciptakan ruang bagi pendidikan. Melalui gerakan di dalam maka LSM perlu menetapkan proses jangka panjang yakni menggunakan lembaga-lembaga yang ada guna

29 Mansour Fakih (1996). The role of non-governmental organizations in social transformation : A participatory inquiry in Indonesia. Disertasi yang dalam edisi berbahasa Indonesia diberi judul Masyarakat sipil untuk transformasi sosial: pergolakan ideologi di dunia LSM Indonesia. Yogyakarta : Pustaka Pelajar, hal. 125 
mencapai perubahan ideologis di kalangan aktivis dan mentransformasikan hubungannya dengan rakyat. Sedangkan melalui gerakan keluar berarti mereka berjuang di gelanggang masyarakat sipil seperti sekolah-sekolah maupun jenis lembaga pendidikan lain. Pada pokoknya, agenda politik aktivis LSM adalah mengupayakan jawaban jangka pendek untuk merespon kebutuhan praktis (war of manuver), dan jangka panjang untuk menanggapi kebutuhan strategis (war of position). War of maneuver senantiasa dilakukan dalam kerangka war of position yakni perjuangan ideologi dan kultural.

Dengan demikian isu strategis dan isu praktis tidak dapat dipisah-pisahkan. Untuk mewujudkan agenda ini LSM Indonesia perlu melakukan tiga langkah berikut. Pertama, melakukan reposisi ideologi aktivis LSM dengan menempatkan dirinya sebagai intelektual organik yakni jenis intelektual yang berakar di dalam kelas yang dieksploitasi dan didominasi. Kedua, menciptakan pendidikan alternatif bagi aktivis seperti riset partisipatif, pendidikan rakyat dan pengalaman mengorganisir petani, sarekat buruh dan jenis gerakan sosial lainnya. Ketiga, perlu memperbaiki kemampuan organisasional dan manajemen gerakan LSM agar punya concern terhadap masalah eksploitasi kelas, penindasan politik, hegemoni kultural, hubungan pengetahuan/kekuasaan, dominasi gender dan tipe deskriminasi lainnya. ${ }^{30}$

Karena itu Fakih merekomendasikan agar perlu studi lanjutan yang bertujuan menciptakan paradigma LSM Indonesia dari teori perubahan sosial dan transformasi sosial. Perlunya studi lanjutan ini juga untuk mencari cara mengintegrasikan kegiatan menjawab kebutuhan praktis rakyat (war of manuever) dengan kegiatan untuk menjawab kebutuhan strategis rakyat, yakni kegiatan jangka panjang (war of position).

\section{Penutup}

Menurut Osmani dengan mengutip hasil penelitian Edward (1999) bahwa kinerja LSM di Asia, Afrika dan Amerika Latin akan berhasil jika mereka mau mengambil tiga cabang strategi berikut ini. Pertama, membantu kaum miskin untuk menjamin atau melindungi mata pencahariannya. Kedua, berupaya memobilisasi masyarakat dengan tujuan untuk memberdayakan masyarakat mis-

30 Ibid., hal. 174 
kin, Ketiga, mencoba mempengaruhi seluruh proses politik dengan melakukan peran pembelaan (advocacy) terhadap kepentingan masyarakat miskin. ${ }^{31}$

Dalam aktifitasnya, LSM secara umum dapat memilih tiga pendekatan berikut ini. Pendekatan Pertama, The Welfare Approach, memberi bantuan kepada kelompok-kelompok tertentu misalnya mereka yang terkena musibah. Pendekatan ini banyak dilakukan kelompok-kelompok keagamaan berupa penyediaan makanan, pelayanan kesehatan dan penyelenggaraan pendidikan bagi mereka yang membutuhkan. Pendekatan kemanusiaan walaupun tidak memberdayakan masyarakat sebagai kelompok sasarannya tetapi dapat memberdayakan NGOs sendiri.

Pendekatan Kedua, The Development Approach, terutama memusatkan program kegiatannya pada pengembangan proyek pembangunan yang bertujuan meningkatkan kemampuan, kemandirian dan keswadayaan masyarakat. Pendekatan pengembangan masyarakat dijalankan dengan berbagai program pendidikan dan latihan bagi tenaga-tenaga NGOs dan pemerintah yang berkecimpung di bidang pemberdayaan rakyat.

Pendekatan Ketiga, The Empowerment Approach, yang melihat kemiskinan sebagai akibat proses politik dan berusaha memberdayakan dan melatih rakyat untuk mengatasi ketidakberdayaannya. Clark berpendapat bahwa telah terjadi pergeseran pendekatan dari sisi penawaran (supply side) yang berkonsentrasi pada pelayanan atau pengadaan proyek pembangunan ke arah sisi permintaan (demand side) dengan memberdayakan rakyat, agar rakyat mempunyai posisi tawar menawar agar dapat menjadi pelaku aktif dalam proses pembangunan. Pendekatan pemberdayaan rakyat bertujuan memperkuat posisi tawar masyarakat lapisan bawah terhadap kekuatan-kekuatan penekan di segala bidang dan sektor kehidupan. Caranya adalah dengan melindungi dan membela pihak yang lemah. Dalam aktifitas pengembangan masyarakat (Community Development) LSM Big NGO's di Indonesia seperti : USC-Satunama, LP3ES, Dian Desa, Walhi, dll. Agaknya sangat memperhatikan pendekatan kedua sebagai jembatan menuju pendekatan ketiga. Masyarakat lapis bawah dan pinggiran perlu diberdayakan karena mereka masih memiliki kelemahan dan kekurangan

31 S.R.Osmani (23 November 1999). Participatory governance, people's empowerment and poverty reduction. Chicago : Seped Conference Papers. Diambil pada tanggal 29 Oktober 2002. dari http://www.undp.org/seped/publications/confpub.html. 
dalam keswadayaan, partisipasi, ketrampilan, sikap kritis, sistem komunikasi personal, wawasan transformatif, rendahnya mutu dan taraf hidup.

Di sisi lain program pengembangan masyarakat yang dijalankan LSM Big'NGOS amat memperhatikan prinsip suistainable development (pembangunan berkelanjutan) yakni proses pembangunan, di mana generasi-generasi mendatang memperoleh modal (capital) sebanyak atau bahkan lebih dengan apa yang diterima oleh generasi sekarang. ${ }^{32}$ Bagi aktivis LSM ini, Capital atau modal yang perlu dijaga kesinambungannya dan diperbaiki meliputi natural capital, physical capital, human capital dan social capital. Untuk dapat membangun secara berkelanjutan salah satunya mempersyaratkan penggunaan manajemen organisasi dalam aktifitas pemberdayaan ekonomi, pendidikan rakyat, dan pengembangan masyarakat.

Untuk langkah ke depan, upaya memberdayakan masyarakat itu setidaktidaknya harus dilakukan melalui tiga cara. Pertama, menciptakan suasana atau iklim yang memungkinkan potensi masyarakat berkembang. Kedua, memperkuat potensi atau daya yang dimiliki oleh rakyat dengan menerapkan langkah-langkah nyata, menampung berbagai masukan, menyediakan prasarana dan sarana baik fisik maupun sosial yang dapat diakses oleh masyarakat lapisan paling bawah. Ketiga, memberdayakan rakyat dalam arti melindungi dan membela kepentingan masyarakat lemah. Dalam proses pemberdayaan harus dicegah jangan sampai yang tidak berdaya bertambah lemah atau makin terpinggirkan dalam menghadapi yang kuat.

Meskipun demikian, selaku LSM tetap perlu menjaga keseimbangan kepentingan dalam merealisasi misi, visi dan program-programnya. Menurut Olena P. Maslyukivska, LSM perlu memberikan pertanggungjawaban pada tiga kelompok yakni kepada patrons, clients dan themselves.

\section{DAFTAR PUSTAKA}

Arikunto, Suharsimi. (1993). Prosedur penelitian. cetakan Kesembilan. Jakarta: Rineka Cipta.

32 Christian Grootaert (1998, No. 3 April). “Social Capital, The Missing Link”. Social capital initiative working papers. New York: The Worl Bank Social Development Family, hal. 1 
Aritonang, Esrom dkk. (2001). Pendampingan komunitas pedesaan. Jakarta: Sekretariat Bina Desa.

Bakker, Anton, H. (1986). Metode-metode filsafat. Jakarta : Ghalia Indonesia.

BPP Tim, YIS (2002). Peningkatan kesejahteraan masyarakat melalui pendampingan kelompok swadaya. Solo: BPP YIS.

Brown, David \& Kalegaonkar, Archana. (1 Juli 1999). Addresing civil society's challenges. IDR Report. Volume 15. Number 2. Diambil pada tanggal 21 Januari 2002. dari http://www.jsj.com/idr/web\%20reports/ html/15-2.html.

Buletin LSM USC-SATUNAMA. Yogyakarta,1994, Edisi IX.

Buletin LSM USC-SATUNAMA. Yogyakarta,1994, Edisi X.

Bunch, Roland. (1992). Dua tongkol jagung. Jakarta: Yayasan Obor Indonesia.

Chambers, Robert. (1983). Rural development, putting the last first. New York: Longman.

Clark, John. (1995). Democratizing Development: The Role of Voluntary Organizations. Terjemahan NGO dan Pembangunan Demokrasi. Yogyakarta: Tiara Wacana.

Clarke, Gerard. (1996). NGOs and oolitics in the developing world. Papers in International Development. No. 20. Centre For Development Studies: University of Wales Swansea.

Darkenwald, G. \& Merriam B. Sharan. (1982). Adult education : foundation of practice. New York : Harper \& Row Publisher.

Fakih, Mansour. (1996). The role of non-governmental organizations in social transformation: A participatory inquiry in Indonesia. Disertasi yang dalam edisi berbahasa Indonesia diberi judul Masyarakat sipil untuk transformasi sosial: pergolakan ideologi di dunia LSM Indonesia. Yogyakarta: Pustaka Pelajar.

Freire, Paulo. (1972). Pedagogy of the oppressed. London: Penguin.

Grootaert, Christian. (1998, No. 3 April). "Social Capital, The Missing Link". Social capital initiative working papers. New York : The Worl Bank Social Development Family.

Hasan, Usman dan Suryanto, Agus. (1997). 1 Juli. Menggugat pemberdayaan ekonomi ummat. PILLAR.

Habibie, B.J. (1984). Ilmu pengetahuan, teknologi dan pembangunan bangsa (Himpunan Pidato). Jakarta : BPPT 
Hadi, Sutrisno. (1987). Metodologi research I. Yogyakarta: Yayasan Penerbitan Fakultas Psikologi UGM.

Hasibuan, S.P., Malayu. (1990). Manajemen dasar, pengertian dan masalah, Jakarta: CV. Haji Masagung.

Hermansyah, Momon. (1995). Pendampingan dan pemberdayaan, Makalah Panduan Untuk Petugas Lapangan dalam Pelatihan Penguatan kelompok P2KP BKM Sidoluhur: Pelatihan KSM Sekar Arum.

Hidayat, Lily. (1995). Pengembangan Ekonomi Rakyat Melalui Agribisnis, dalam Suwarto. Yuni dan Aris Santoso (Ed.). Ekonomi rakyat antara gagasan dan realita (hlm. 93-99). Jakarta: Sekretariat Bina Desa.

Ife, Jim. (1997). Community development, Melbourne: Addison Wesley Longman Iswardono, Permono, S. (1999). Ekonomi, kerakyatan; sekedar jargon politik, Jurnal Ekonomi dan Bisnis Indonesia.

Jalal, Kazi, F. (1999). Study of NGO. regional overview report. Manila, ADB.

Kamus besar bahasa Indonesia. (2000) Departemen Pendidikan dan Kebudayaan Republik Indonesia Jakarta: cet. XII. 2000.

Kartasasmita, Ginandjar. (1996). Pembangunan untuk rakyat. Jakarta: PT. Pustaka CIDESINDO.

Kenny, Susan. (1994). Developing communities for the future. Melbourne: An International Thomson Publishing Company.

Koentjoroningrat, M. (1999). Metode penelitian masyarakat. Jakarta: Gramedia.

Martuti, Anik Dwi. (1995). Ekonomi rakyat antara gagasan dan realita. Jakarta: Sekretariat Bina Desa.

Marzuki, Kurdi. (2001). Tahapan Pengorganisasiaan Rakyat Sebuah Pengalaman Simpul belajar kita. Jakarta: Yayasan Patria Nusantara.

Miles, John \& Huberman, Michael, A. (1994). An expanded source book: qualitative data analysis. California: Sage Publication.

Moleong, Lexy. J. (1983). Metodologi penelitian kualitatif. Bandung: PT. Remaja Rosdakarya.

Mubyarto. (1997). Ekonomi rakyat, program IDT, dan demokrasi ekonomi Indonesia. Yogyakarta : Aditya Media.

Nadzir, Muhammad. (1998). Metode penelitian. Jakarta: Ghalia Indonesia.

Nagy, Magdolna. (1 Januari 1994). Manual on public pin Enviromental decision making. "Papers UNDP". Budapest. Diambil pada tanggal 12 Agustus 2000, dari http://www.rec.org/default.html. 
Nugroho, Heru. (2000). Menumbuhkan ide-ide kritis. Yogyakarta: Pustaka Pelajar.

Olena, Maslyukivska, P. (1999) Role of non-govermental organizations in development coorperation. UNDP/Yale Collaborative Programme: Research Papers.

Osmani, S.R. (23 November 1999). Participatory governance, people's empowerment and poverty reduction. Chicago : Seped Conference Papers. Diambil pada tanggal 29 Oktober 2002. dari http://www.undp.org/seped/publications/confpub.html.

Panduan penguatan manajemen LSM. (1999). Jakarta : Sekretariat Bina Desa.

Prijono, Ony, S. (1996). Pemberdayaan; konsep, kebijakan dan implementasi, Jakarta:

Centre for Strategic and International Studies (CSIS).

Rogers, Everett. M. and Shoemaker, Floyd. F.(1971, Edisi 2). Communication of innovation a croos-cultural approach. New York (USA): The Free Press.

Safei, Ahmad Agus. (2001). Manajemen pengembangan masyarakat Islam. Bandung: Gerbang Masyarakat Baru Press.

Santoso, Abdul Fatah. (1997). Pengembangan masyarakat melalui pesantren: mencari akar teologis. Yogyakarta: Pustaka Pelajar.

Syafi'i, Antonio. (1997). 1 Juli. Ada yang sengaja bodohkan umat. PILLAR.

Siagian, Sondang. P. (2001). Manajemen sumber daya manusia. Jakarta: Bumi Aksara.

Singarimbun, Masri \& Effendi, Sofian. (1982). Metode penelitian survai, Cetakan Kedua. Jakarta: LP3ES.

Sudarsono, F.X. (1995). Analisis data. Makalah disampaikan pada penataran Penelitian Kualitatif IKIP Yogyakarta: 16-18 Februari 1995.

Suwarto, Yuni \& Saiful Bahari. (1995). Pola Pengembangan Ekonomi Rakyat. dalam Suwarto. Yuni dan Aris Santoso (Ed.). Ekonomi rakyat antara gagasan dan realita. Jakarta: Sekretariat Bina Desa.

Terry, George. R. dan Rue, Leslie. W (2001). Dasar-dasar manajemen, Cetakan Kedelapan. Jakarta: Bumi Aksara.

Vidhyandika, Moelyarto. (1996). Pemberdayaan, konsep, kebijakan dan implementasi. Jakarta: Centre for Strategic and International Studies (CSIS)

Wijaya, Faried. (1987). Pengantar ekonomi. Yogyakarta: Femosa.

Yakub, H.M. (1985). Pondok pesantren dan pembangunan masyarakat desa Bandung: Angkasa. 
